\title{
Phylogenetic relationships of Chilean leptodactylids: a molecular approach based on mitochondrial genes $12 \mathrm{~S}$ and $16 \mathrm{~S}$
}

\author{
Relaciones filogenéticas de los leptodactílidos chilenos: una aproximación molecular \\ basada en los genes mitocondriales $12 \mathrm{~S}$ y $16 \mathrm{~S}$
}

\author{
CLAUDIO CORREA ${ }^{1,3}$, ALBERTO VELOSO $^{1}$, PATRICIA ITURRA $^{2} \&$ MARCO A. MÉNDEZ $3,4 *$ \\ ${ }^{1}$ Departamento de Ciencias Ecológicas, Facultad de Ciencias, Universidad de Chile, Casilla 653, Santiago, Chile \\ ${ }^{2}$ Programa de Genética Humana, ICBM, Facultad de Medicina, Universidad de Chile, Santiago, Chile \\ ${ }^{3}$ Laboratorio de Genómica Evolutiva, INTA, Universidad de Chile, Macul 5540, Casilla 138-11, Santiago, Chile \\ ${ }^{4}$ Center for Advanced Studies in Ecology \& Biodiversity and Departamento de Ecología, \\ Pontificia Universidad Católica de Chile, Santiago, Chile \\ *e-mail for correspondence: mmendez@inta.cl
}

\begin{abstract}
Most Chilean amphibians belong to the subfamily Telmatobiinae (Anura, Leptodactylidae). Several phylogenetic studies of Leptodactylidae and Telmatobiinae, based principally on morphological characters, have implicitly suggested closer relationships of some species of the Telmatobiinae with members of other subfamilies of leptodactylids, including the leptodactyline genus Pleurodema which is present in Chile. Furthermore, a growing number of molecular studies suggest a non monophyletic status for Telmatobiinae, although none of these studies have investigated the phylogenetic relationships of this subfamily. We compared partial sequences of the ribosomal mitochondrial genes $12 \mathrm{~S}$ and $16 \mathrm{~S}$ to determine the phylogenetic relationships of Chilean leptodactylids and its position within the modern anurans (Neobatrachia). We included 22 species from nine of the 10 genera of telmatobiines present in Chile (Alsodes, Atelognathus, Batrachyla, Caudiverbera, Eupsophus, Hylorina, Insuetophrynus, Telmatobufo and Telmatobius), two species of the genus Pleurodema, and one species of Rhinodermatidae, which is considered a leptodactylid derivative family by some authors. We also included 51 species representing most of the families that compose Neobatrachia. Phylogenetic reconstructions were performed using the methods of maximum parsimony, maximum likelihood and Bayesian inference. The topologies obtained in all the analyses indicate that Telmatobiinae is a polyphyletic assemblage, composed by species belonging to Hyloidea (most of the genera) and species more related to Australasian taxa (the clade Caudiverbera + Telmatobufo, defined as the tribe Calyptocephalellini). These molecular data support groups based on other kinds of evidence (Caudiverbera + Telmatobufo, Alsodes + Eupsophus and Batrachyla + Hylorina) and raise new phylogenetic hypotheses for several genera of telmatobiines (Atelognathus with Batrachyla and Hylorina, Insuetophrynus + Rhinoderma) The phylogenetic relationships recovered in this study suggest a multiple origin for Chilean temperate forest frogs and reveal an unexpected level of taxonomic diversity and evolutionary divergence among Chilean leptodactylids.
\end{abstract}

Key words: Telmatobiinae, Calyptocephalellini, Rhinodermatidae, ribosomal mitochondrial genes, phylogenetic reconstruction.

\section{RESUMEN}

La mayoría de los anfibios chilenos pertenece a la subfamilia Telmatobiinae (Anura, Leptodactylidae). Varios estudios filogenéticos de Leptodactylidae y Telmatobiinae, basados principalmente en caracteres morfológicos, han sugerido implícitamente relaciones más estrechas de algunas especies de Telmatobiinae con miembros de otras subfamilias de leptodactílidos, incluyendo el género leptodactilino Pleurodema presente en Chile. Además, un número creciente de estudios moleculares sugieren un estatus no monofilético para Telmatobiinae, aunque ninguno de estos estudios ha investigado las relaciones filogenéticas de esta subfamilia. Secuencias parciales de los genes ribosomales mitocondriales $12 \mathrm{~S}$ y $16 \mathrm{~S}$ fueron comparadas para determinar las relaciones filogenéticas de los leptodactílidos chilenos y su posición dentro de los anuros modernos (Neobatrachia). Se incluyeron 22 especies de nueve de los diez géneros de telmatobinos presentes en Chile (Alsodes, Atelognathus, Batrachyla, Caudiverbera, Eupsophus, Hylorina, Insuetophrynus, Telmatobufo y Telmatobius), dos especies del género Pleurodema y una especie de Rhinodermatidae la cual 
es considerada una familia derivada de los leptodactílidos por algunos autores. Se incluyeron además 51 especies que representan la mayoría de las familias que componen Neobatrachia. Las reconstrucciones filogenéticas se realizaron utilizando los métodos de máxima parsimonia, máxima verosimilitud e inferencia bayesiana. Las topologías obtenidas en todos los análisis indican que Telmatobiinae es un ensamblaje polifilético, compuesto por especies que pertenecen a Hyloidea (la mayoría de los géneros) y especies más relacionadas con taxa de Australasia (el clado Caudiverbera + Telmatobufo, definido como la tribu Calyptocephalellini). Estos datos moleculares respaldan agrupaciones basadas en otro tipo de evidencia (Caudiverbera + Telmatobufo, Alsodes + Eupsophus y Batrachyla + Hylorina $)$ y plantean nuevas hipótesis de relaciones para algunos géneros de telmatobinos (Atelognathus con Batrachyla e Hylorina, Insuetophrynus + Rhinoderma). Las relaciones filogenéticas observadas en este estudio sugieren un origen múltiple para los anuros del bosque templado de Chile y revelan un inesperado nivel de diversidad taxonómica y divergencia evolutiva entre los leptodactílidos chilenos.

Palabras clave: Telmatobiinae, Calyptocephalellini, Rhinodermatidae, genes ribosomales mitocondriales, reconstrucción filogenética.

\section{INTRODUCTION}

Chilean amphibians belong to three families of anurans included in Hyloidea (formerly known as Bufonoidea), which constitutes one of the informal divisions of modern anurans (Neobatrachia) (Lynch 1973, Darst \& Cannatella 2004). Most of the species (84\%) belong to the family Leptodactylidae; up to the present 42 species have been described belonging to 11 genera (Díaz-Páez \& Ortiz 2003). Only two of the five recognized subfamilies of leptodactylids (Frost 2004) have representatives in Chile and the great majority, 39 species, is included in the subfamily Telmatobiinae. From a biogeographic point of view, it is important to note that ten of the 12 genera of this subfamily have representatives in Chile, with a large number of endemic species (Veloso \& Navarro 1988, Formas 1995). The endemic taxa include the monotypic genera Caudiverbera and Insuetophrynus, the genus Telmatobufo (three species), and various species of the genera Telmatobius (from the Altiplano at the northern limit of the country), Alsodes and Eupsophus (both with numerous endemic species from center-south of Chile). The other two families represented are Bufonidae (six species), which has a nearly cosmopolitan distribution, and Rhinodermatidae (two species), which is restricted to the center-south forests from Chile (between $35^{\circ}$ and $47^{\circ} \mathrm{S}$ ) and a small region of Argentina.

The origin of the leptodactylids appears to have been in the late Cretaceous, associated with the temperate forest of the southern part of South America, and it is considered that telmatobiines represent a remnant of the stock that originated the rest of the lineages of the family (Cei 1962, Vuilleumier 1968, Lynch 1971, Savage 1973, Heyer 1975, Formas 1979, Duellman \& Trueb 1994). Among the leptodactylids, the more ancient fossil records correspond to telmatobiines from the early Cenozoic in the region which is currently the Argentinean Patagonia, which once was covered by forest (Schaeffer 1949, Lynch 1971, Báez \& Gasparini 1979). As the extension of the temperate forests progressively decreased during the late Cenozoic, the distribution of the subfamily became restricted mainly to a southwestern South American region, which is currently Chilean territory, and to a narrow area bordering Argentina. Thus, eight of the 12 genera have representatives in the temperate forests of southern Chile and Argentina; some of the species present specialized adaptations to these environments (Formas 1979). The other frog lineage that presents a similar distribution and profound adaptations to the forest is the family Rhinodermatidae, which from a systematic point of view, is considered a leptodactylid derivative by some authors (Savage 1973, Díaz \& Veloso 1979).

The classical phylogenetic studies of the Leptodactylidae (Lynch 1971, Heyer 1975) indicate that the telmatobiines diverged early in the phylogeny of the family together with the members of the subfamily Ceratophryinae (Fig. $1 \mathrm{~A}$ and $1 \mathrm{~B})$. On the other hand, systematic studies of telmatobiines which used morphological, karyological and/or molecular characters (immunological methods, hepatic hexokinase and lactate dehydrogenase enzyme systems) indicate that this subfamily constitutes 

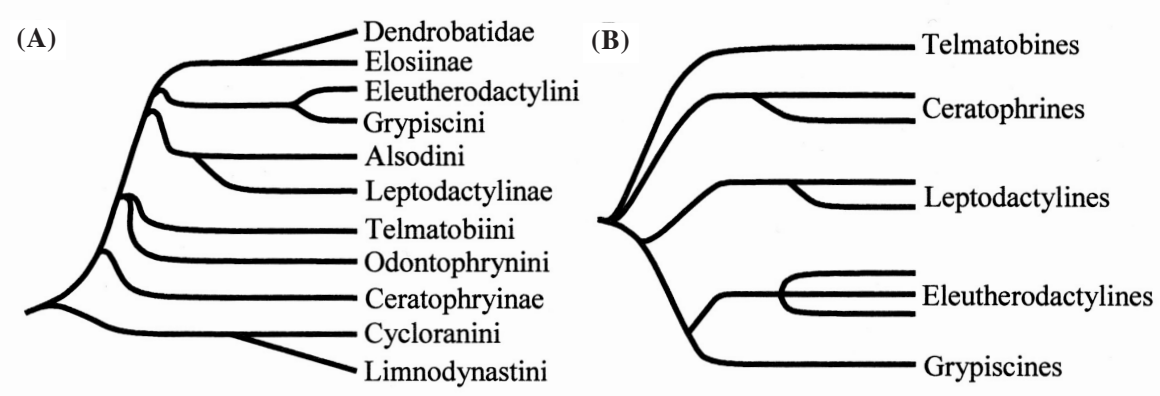

(C)
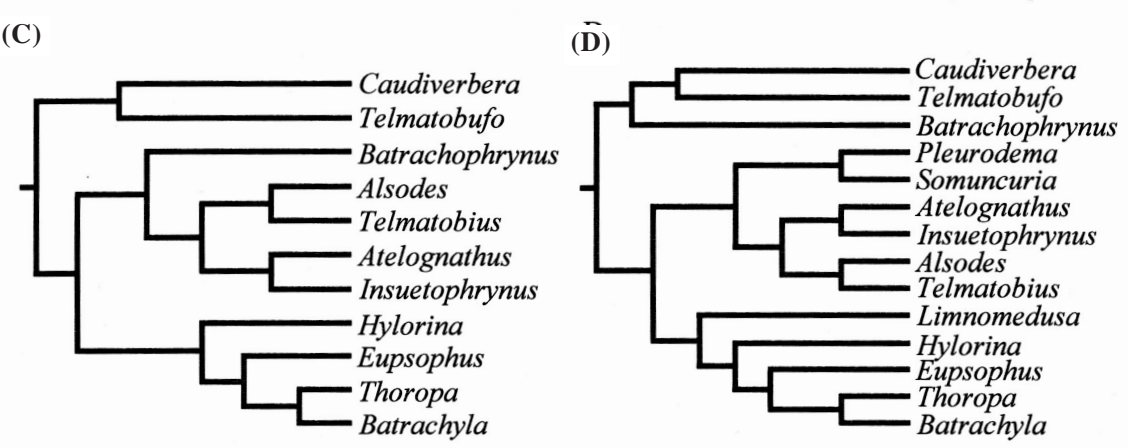

(E)

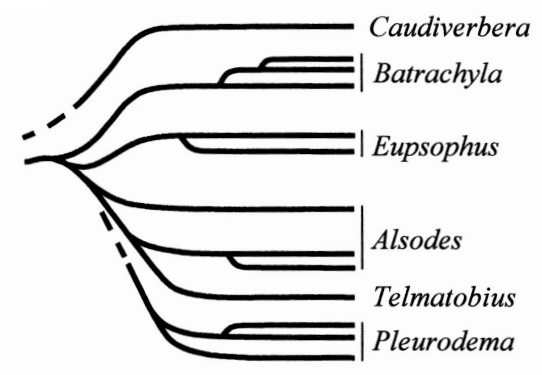

(F)

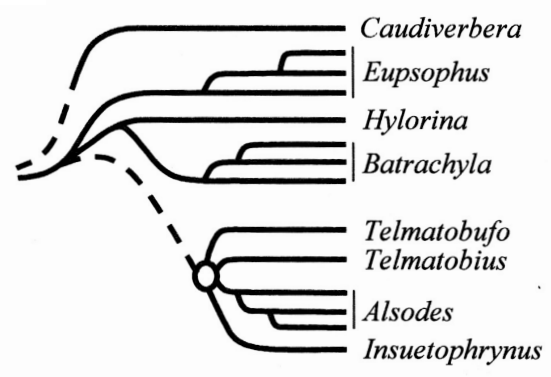

Fig. 1: Phylogenetic hypotheses proposed for Leptodactylidae (A) and (B) and Telmatobiinae (C), (D), (E) and (F) by several authors. (A): Lynch (1971), a scheme of the within-family relationships of the leptodactylids based largely on morphological evidence; according to this author the subfamily Telmatobiinae is composed of the tribes Alsodini, Eleutherodactylini, Grypiscini, Odontophrynini and Telmatobiini. (B): Heyer (1975), relationships among the five informal groups defined by this author inferred by means of cladistic analyses of 37 characters (principally morphological). (C) and (D): Lynch (1978), cladograms obtained by two analyses of 19 characters (mainly osteological) of 11 (C) and 14 taxa (D) of leptodactylids; (C) includes only telmatobiines, while (D) includes the leptodactylines Pleurodema and Limnomedusa. (E): Díaz \& Veloso (1979), scheme of the intergeneric relationships of Chilean leptodactylids based principally on karyological characters and hepatic hexokinase patterns; the leptodactyline genus Pleurodema was included in this study. (F): Díaz (1986), phylogenetic relationships of Chilean telmatobiines obtained by a cladistic analysis of 13 characters (principally morphological). The classifications derived from these studies are given in Table 1 .

Hipótesis filogenéticas propuestas para Leptodactylidae (A) y (B) y Telmatobiinae (C), (D), (E) y (F) por varios autores. (A): Lynch (1971), un esquema de las relaciones intrafamiliares de los leptodactílidos basado principalmente en evidencia morfológica; de acuerdo a este autor la subfamilia Telmatobiinae está compuesta por las tribus Alsodini, Eleutherodactylini, Grypiscini, Odontophrynini and Telmatobiini. (B): Heyer (1975), relaciones entre las cinco agrupaciones informales definidas por este autor, inferidas a partir de 37 caracteres (principalmente morfológicos). (C) y (D): Lynch (1978), cladogramas obtenidos en dos análisis de 19 caracteres (principalmente osteológicos) de 11 (C) y 14 taxa (D) leptodactílidos; (C) incluye solo telmatobinos, mientras (D) incluye además los leptodactilinos Pleurodema and Limnomedusa. (E): Díaz \& Veloso (1979), esquema de las relaciones intergenéricas de leptodactílidos chilenos basado principalmente en caracteres cariológicos y patrones de hexoquinasas hepáticas; el género leptodactilino Pleurodema fue incluido en este estudio. (F): Díaz (1986), relaciones filogenéticas de los telmatobinos chilenos obtenidas por un análisis cladístico de 13 caracteres (principalmente morfológicos). Las clasificaciones derivadas de estos estudios son dadas en la Tabla 1. 
a monophyletic group (Cei 1970, Barrio \& Rinaldi de Chieri 1971, Lynch 1978, Díaz \& Veloso 1979, Díaz 1986). Several authors proposed phylogenetic hypotheses and alternative classifications for this subfamily (Lynch 1978, Díaz \& Veloso 1979, Díaz 1986) (Table 1, Fig. 1C, 1D, 1E and 1F). One common aspect of these studies was the recognition of Caudiverbera as the more divergent genus. The morphological divergence of Caudiverbera has been emphasized by several authors (Reig 1960, Cei 1970, Díaz \& Veloso 1979, Díaz 1986); two of them suggested a separate subfamily for this genus (Reig 1960, Díaz 1986). Also, several studies based on morphological and karyological evidence have grouped this genus with Telmatobufo (Formas \& Espinoza 1975, Lynch 1978), together forming the tribe Calyptocephalellini of Lynch (1978) (Fig. 1C, Table 1). Although the monophyletic nature of Telmatobiinae was not questioned in the majority of these studies, the topologies obtained by Lynch $(1971,1978)$ suggested closer relationships of some telmatobiines with species of other subfamilies (Fig. 1A and 1D), results which were not considered by this author in his taxonomic conclusions. One of those taxa is Pleurodema, which could be related with the telmatobiine genus Eupsophus (Duellman \& Veloso 1977).

The systematic problems are also present at the family level. Although the use of Leptodactylidae has been maintained, there is morphological evidence and biogeographical antecedents that permit one to question its taxonomic validity (Lynch 1971, Ford \& Cannatella 1993, Duellman \& Trueb 1994, Haas 2003). Furthermore, a growing number of molecular studies show that certain species of this family are more related to other anuran taxa (Ruvinsky \& Maxson 1996, Vences et al. 2000, 2003, Darst \& Cannatella 2004, Faivovich et al. 2005, San Mauro et al. 2005, Wiens et al. 2005). The last four studies have special relevance for the systematics of Leptodactylidae and Telmatobiinae. Even though Darst \& Cannatella (2004) investigated the relationships among other hyloid taxa, they indicated with an extensive sampling, which included species of four subfamilies of Leptodactylidae and two genera of Telmatobiinae, that this family is polyphyletic.
Faivovich et al. (2005), in a systematic and taxonomic study of the family Hylidae, obtained a similar result including species from the five subfamilies of Leptodactylidae and a greater number of telmatobiine species in the outgroup. On the other hand, San Mauro et al. (2005), in a study about the divergence times of the major amphibian lineages obtained through nuclear gene Rag-1, showed that Caudiverbera is related to one species of the Australasian family Myobatrachidae and it is not related to other hyloid species (among which only one leptodactylid species of the genus Telmatobius was included). The relationship of Caudiverbera with species of Australasian families was corroborated by Wiens et al. (2005), including a greater number of leptodactylid species, but only one species of Telmatobiinae of the genus Telmatobius.

None of the above molecular studies intended to investigate the phylogenetic relationships of Leptodactylidae, Telmatobiinae or Rhinodermatidae. Furthermore, those studies did not include a significant number of species of the subfamily Telmatobiinae nor did it include either species of the family Rhinodermatidae. Considering the new findings of those molecular analysis and their systematic implications, which contrast with previous hypotheses based in the morphology, the objectives of the present study are to investigate the phylogenetic relationships of Chilean species of leptodactylids and Rhinodermatidae, and specifically to establish the systematic position of the Telmatobiinae with respect to other hyloid lineages.

\section{MATERIAL AND METHODS}

We chose 24 species of Chilean leptodactylids belonging to 10 genera and two subfamilies, and one species of the family Rhinodermatidae (Table 2). The only telmatobiinae genus that inhabits Chile that could not be included was Telmalsodes. We could not extract DNA from formalin fixed tissues, the only available material of this taxon. In order to account for intrageneric variation, we incorporated more than one species from most genera of Chilean leptodactylids. We also included 16 species of the other four recognized subfamilies of leptodactylids and 35 of other 20 neobatrachian 
TABLE 1

Classifications proposed for the family Leptodactylidae (A), the subfamily Telmatobiinae (B) and the Chilean leptodactylids $(\mathrm{C})$ by several authors. In the classifications of Leptodactylidae only the genera belonging to the subfamily Telmatobiinae or equivalent tribes are indicated. With the exception of Frost (2004), all the classifications are based on phylogenetic studies (Fig. 1). The genus Telmalsodes (Díaz 1989), which does not appear in these classifications neither is incorporated in this study, is included in the most recent reviews of Chilean amphibians (Formas 1995, Díaz-Páez \& Ortiz 2003), but is considered as part of Alsodes by Frost (2004). Note that Rhinoderma is included by Díaz \& Veloso (1979) in Leptodactylidae with subfamilial status

Clasificaciones propuestas para la familia Leptodactylidae (A), la subfamilia Telmatobiinae (B) y los leptodactílidos chilenos (C) por varios autores. En las clasificaciones de Leptodactylidae solo se indican los géneros pertenecientes a la subfamilia Telmatobiinae o tribus equivalentes. Con la excepción de Frost (2004), todas las clasificaciones se basan en estudios filogenéticos (Fig. 1). El género Telmalsodes (Díaz 1989), que no aparece en estas clasificaciones ni fue incorporado en este estudio, es incluido en las revisiones más recientes de los anfibios chilenos (Formas 1995, Díaz-Páez \& Ortiz 2003), pero es considerado como parte de Alsodes por Frost (2004). Note que Rhinoderma es incluido por Díaz \& Veloso (1979) en Leptodactylidae con estatus de subfamilia

(A) Leptodactylidae

\begin{tabular}{|c|c|c|}
\hline Lynch (1971) & Heyer (1975) & Frost (2004) \\
\hline Subfamily Ceratophryinae & Group Ceratophrines & Subfamily Ceratophryinae \\
\hline Subfamily Cycloraninae & Group Eleutherodactylines & Subfamily Cycloramphinae \\
\hline Subfamily Elosiinae & Group Grypiscines & Subfamily Eleutherodactylinae \\
\hline Subfamily Heleophryninae & Group Leptodactylines & Subfamily Leptodactylinae \\
\hline Subfamily Leptodactylinae & Group Telmatobines: & Subfamily Telmatobiinae: \\
\hline Subfamily Telmatobiinae: & Batrachyla & Atelognathus \\
\hline Tribe Alsodini: & Caudiverbera & Batrachophrynus \\
\hline Batrachyla & Eupsophus & Batrachyla \\
\hline Eupsophus & Hylorina & Caudiverbera \\
\hline Hylorina & Insuetophrynus & Eupsophus \\
\hline Tribe Telmatobiini: & & Telmatobufo \\
\hline \multicolumn{3}{|l|}{ Batrachophrynus } \\
\hline \multicolumn{3}{|l|}{ Caudiverbera } \\
\hline \multicolumn{3}{|l|}{ Telmatobius } \\
\hline Telmatobufo & & \\
\hline
\end{tabular}

\begin{tabular}{ll}
\hline (B) Telmatobiinae & (C) Chilean leptodactylids
\end{tabular}

\begin{tabular}{lcc}
\hline Lynch (1978) & Díaz \& Veloso (1979) & Díaz (1986) \\
\hline Tribe Calyptocephalellini: & Subfamily Telmatobiinae: & Subfamily Calyptocephalellinae: \\
Caudiverbera & Caudiverbera & Caudiverbera \\
Telmatobufo & Telmatobufo & Subfamily Telmatobiinae: \\
Tribe Telmatobiini: & Eupsophus & Tribe Alsodini: \\
Alsodes & Batrachyla & Batrachyla \\
Atelognathus & Hylorina & Eupsophus \\
Batrachophrynus & Alsodes & Hylorina \\
Eupsophus & Telmatobius & Tribe Telmatobiini: \\
Hylorina & Insuetophrynus & Telmatobius \\
Insuetophrynus & Pubfamily Leptodactylinae: & Alsodes \\
Limnomedusa & Pleurodema & Insuetophrynus \\
Somuncuria & Subfamily Rhinodermatinae: & Telmatobufo \\
Tribe Batrachylini: & Rhinoderma & Atelognathus \\
Batrachyla & & Subfamily Leptodactylinae: \\
Thoropa & & Pleurodema
\end{tabular}


families, for which we obtained published sequences of the $12 \mathrm{~S}$ and $16 \mathrm{~S}$ genes (see references in Table 3). We used four archaeobatrachian species of the families Pipidae, Pelobatidae and Pelodytidae (Table 3) as outgroup, based on molecular systematic studies of Anura (Hoegg et al. 2004, Roelants \& Bossuyt 2005, San Mauro et al. 2005). The taxonomic assignment of all species was made according to Frost (2004). The newly obtained sequences were deposited in GenBank with accession numbers DQ864523-DQ864541 for $12 \mathrm{~S}$ and DQ864542-DQ864566 for $16 \mathrm{~S}$. We also included $12 \mathrm{~S}$ sequences previously published with accession numbers AY578817AY578822 (Veloso et al. 2005).

TABLE 2

Species of Chilean amphibians included in this study. The locality and collection number of each specimen are indicated. The species Atelognathus jeinimenensis (Meriggio et al. 2004) and Eupsophus queulensis (Veloso et al. 2005) were recently described, which is why they do not appear in Díaz-Páez \& Ortiz (2003). All the genera are classified in the subfamily Telmatobiinae

(Frost 2004) except for Pleurodema (subfamily Leptodactylinae) and Rhinoderma (family

Rhinodermatidae). IZUA: Instituto de Zoología de la Universidad Austral (Chile). DBGUCH: Departamento de Biología Celular y Genética de la Universidad de Chile. MZUC: Museo de Zoología de la Universidad de Concepción (Chile). WCN: without collection number

Especies de anfibios chilenos incluidos en este estudio. Se indican la localidad y el número de colección de cada espécimen. Las especies Atelognathus jeinimenensis (Meriggio et al. 2004) y Eupsophus queulensis (Veloso et al. 2005) fueron descritas recientemente, por lo que no aparecen en Díaz-Páez \& Ortiz (2003). Todos los géneros son clasificados en la subfamilia Telmatobiinae (Frost 2004), excepto Pleurodema (subfamilia Leptodactylinae) y Rhinoderma (familia Rhinodermatidae). IZUA: Instituto de Zoología de la Universidad Austral (Chile). DBGUCH: Departamento de Biología Celular y Genética de la Universidad de Chile. MZUC: Museo de Zoología de la Universidad de Concepción (Chile). WCN: sin número de colección

\begin{tabular}{|c|c|c|}
\hline Species & Locality, Administrative Region of Chile & Collection number \\
\hline Alsodes barrioi & Piedra del Águila, 8th & IZUA 3213 \\
\hline Alsodes monticola & Puente La Herradura, 10th & DBGUCH 2919 \\
\hline Alsodes nodosus & Tiltil, Metropolitan & DBGUCH WCN \\
\hline Alsodes sp. & Futaleufú, 10th & DBGUCH 3372 \\
\hline Alsodes tumultuosus & La Parva, Metropolitan & IZUA WCN \\
\hline Atelognathus jeinimenensis & Laguna Jeinimeni, 11th & DBGUCH 3438 \\
\hline Batrachyla antartandica & Cuesta Bahamondes, 10th & DBGUCH 2959 \\
\hline Batrachyla leptopus & Hueyelhue, 10th & DBGUCH 2977 \\
\hline Batrachyla taeniata & Llico Bajo, 10th & DBGUCH 2943 \\
\hline Caudiverbera caudiverbera & Pantano La Barra, 10th & DBGUCH 3028 \\
\hline Eupsophus calcaratus & Bosque mixto 3,10 th & DBGUCH 2904 \\
\hline Eupsophus emiliopugini & Cucao, 10th & DBGUCH 3342 \\
\hline Eupsophus migueli & Mehuín, 10th & IZUA 3476 \\
\hline Eupsophus queulensis & Los Queules, 7th & DBGUCH 3273 \\
\hline Eupsophus roseus & La Saval, 10th & IZUA 3506 \\
\hline Hylorina sylvatica & Lagunas Gemelas, 10th & DBGUCH 3031 \\
\hline Insuetophrynus acarpicus & Queule, 9th & DBGUCH 3125 \\
\hline Pleurodema marmorata & Lauca, 1st & DBGUCH 2725 \\
\hline Pleurodema thaul & Llico Bajo, 10th & DBGUCH 2918 \\
\hline Rhinoderma darwinii & Nahuelbuta, 8th & DBGUCH WCN \\
\hline Telmatobius marmoratus & Caquena, 1st & DBGUCH 3384 \\
\hline Telmatobius vilamensis & Vilama, 2nd & IZUA 3080 \\
\hline Telmatobius zapahuirensis & Zapahuira, 1st & DBGUCH 3382 \\
\hline Telmatobufo bullocki & Caramávida, 8th & MZUC WCN \\
\hline Telmatobufo venustus & Altos de Vilches, 7th & IZUA 3054 \\
\hline
\end{tabular}


TABLE 3

Species of leptodactylids and of other familes for which already published sequences of the $12 \mathrm{~S}$ and $16 \mathrm{~S}$ genes were obtained. GenBank accession numbers, the study in which the sequences were utilized (Reference 1: Biju \& Bossuyt 2003; 2: Darst \& Cannatella 2004; 3: Faivovich et al. 2005; 4: Roe et al. 1985) and the family or subfamily (only for hylid and leptodactylid species) in which these species are classified (Frost 2004) are indicated. For sequences obtained from references 2 and 3 , only one accession number is indicated since those fragments include part of the $12 \mathrm{~S}$ and

$16 \mathrm{~S}$ genes. The accession number of Xenopus laevis corresponds to that of a complete mitochondrial genome sequence (Roe et al. 1985). The names of the species marked with an asterisk were updated with respect to those of GenBank according to the taxonomic changes proposed by Lehr et al. (2005) (Phrynopus brunneus) and Crawford \& Smith (2005) (Craugastor fitzingeri)

Especies de leptodactílidos y de otras familias de las cuales se obtuvieron secuencias de los genes $12 \mathrm{~S}$ y $16 \mathrm{~S}$ ya publicadas. Se indican los números de acceso de GenBank, el estudio en que fueron utilizadas (Referencia 1: Biju \& Bossuyt 2003; 2: Darst \& Cannatella 2004; 3: Faivovich et al. 2005; 4: Roe et al. 1985) y la familia o subfamilia (solo para las especies de las familias Hylidae y Leptodactylidae) en que estas especies son clasificadas (Frost 2004). Para las secuencias obtenidas de las referencias 2 y 3 , se indica solo un número de acceso ya que esos fragmentos incluyen parte de los genes $12 \mathrm{~S}$ y $16 \mathrm{~S}$. El número de acceso de Xenopus laevis corresponde a una secuencia completa del genoma mitocondrial (Roe et al. 1985). Los nombres de las especies marcadas con un asterisco fueron actualizados con respecto a los de GenBank de acuerdo a los cambios taxonómicos propuestos por Lehr et al. (2005) (Phrynopus brunneus) y Crawford \& Smith (2005) (Craugastor fitzingeri)

\begin{tabular}{|c|c|c|c|}
\hline Species & Accession number & Reference & Classification \\
\hline Acris crepitans & AY843559 & 3 & Hylinae \\
\hline Adenomera sp. & AY843561 & 3 & Leptodactylinae \\
\hline Allophryne ruthveni & AY843564 & 3 & Allophrynidae \\
\hline Brachycephalus ephippium & AY326008 & 2 & Brachycephalidae \\
\hline Bufo arenarum & AY843573 & 3 & Bufonidae \\
\hline Bufo boreas & AY325983 & 2 & Bufonidae \\
\hline Callulina kreffti & AY326068 & 2 & Microhylidae \\
\hline Centrolene prosoblepon & AY 843574 & 3 & Centrolenidae \\
\hline Ceratophrys cranwelli & AY843575 & 3 & Ceratophryinae \\
\hline Colostethus talamancae & AY843577 & 3 & Dendrobatidae \\
\hline Craugastor fitzingeri* ${ }^{*}$ & AY326001 & 2 & Eleutherodactylinae \\
\hline Crossodactylus schmidti & AY843579 & 3 & Cycloramphinae \\
\hline Cryptobatrachus sp. & AY326050 & 2 & Hemiphractinae \\
\hline Dendrobates auratus & AY843581 & 3 & Dendrobatidae \\
\hline Dendrophryniscus minutus & AY843582 & 3 & Bufonidae \\
\hline Edalorhina perezi & AY843585 & 3 & Leptodactylinae \\
\hline Eleutherodactylus chloronotus & AY326007 & 2 & Eleutherodactylinae \\
\hline Eleutherodactylus duellmani & AY326003 & 2 & Eleutherodactylinae \\
\hline Eleutherodactylus thymelensis & AY326009 & 2 & Eleutherodactylinae \\
\hline Eleutherodactylus w-nigrum & AY326004 & 2 & Eleutherodactylinae \\
\hline Gastrotheca cornuta & AY843591 & 3 & Hemiphractinae \\
\hline Heleophryne purcelli & AY364356, AY364377 & 1 & Heleophrynidae \\
\hline Hemiphractus helioi & A Y 843594 & 3 & Hemiphractinae \\
\hline Hemisus marmoratus & AY326070 & 2 & Hemisotidae \\
\hline Hyla armata & AY549321 & 3 & Hylinae \\
\hline Hyperolius sp. & AY326069 & 2 & Hyperoliidae \\
\hline Lepidobatrachus sp. & AY326019 & 2 & Ceratophryinae \\
\hline Leptodactylus ocellatus & AY843688 & 3 & Leptodactylinae \\
\hline Limnodynastes salmini & AY326071 & 2 & Limnodynastidae \\
\hline Limnomedusa macroglossa & AY843689 & 3 & Leptodactylinae \\
\hline Litoria caerulea & AY843692 & 3 & Pelodryadinae \\
\hline
\end{tabular}


TABLE 3 (continuation)

\begin{tabular}{|c|c|c|c|}
\hline Species & Accession number & Reference & Classification \\
\hline Mantidactylus femoralis & AY843698 & 3 & Mantellidae \\
\hline Myobatrachus gouldii & AY364361, AY364382 & 1 & Myobatrachidae \\
\hline Nasikabatrachus sahyadrensis & AY364360, AY364381 & 1 & Nasikabatrachidae \\
\hline Neobatrachus sudelli & AY843700 & 3 & Limnodynastidae \\
\hline Nesomantis thomasseti & AY364352, AY364373 & 1 & Sooglossidae \\
\hline Odontophrynus americanus & AY843704 & 3 & Ceratophryinae \\
\hline Osteocephalus taurinus & AY843709 & 3 & Hylinae \\
\hline Pelobates cultripes & AY364341, AY364363 & 1 & Pelobatydae \\
\hline Pelodytes punctatus & AY364343, AY364365 & 1 & Pelodytidae \\
\hline Petropedetes parkeri & AY364348, AY364369 & 1 & Petropedetidae \\
\hline Pipa pipa & AY364344, AY364366 & 1 & Pipidae \\
\hline Phrynopus brunneus* & AY843720 & 3 & Eleutherodactylinae \\
\hline Physalaemus cuvieri & AY843729 & 3 & Leptodactylinae \\
\hline Pseudopaludicola falcipes & AY843741 & 3 & Leptodactylinae \\
\hline Pseudis paradoxa & AY843740 & 3 & Hylinae \\
\hline Pseudophryne bibroni & AY843742 & 3 & Myobatrachidae \\
\hline Rhacophorus bipunctatus & AY843750 & 3 & Rhacophoridae \\
\hline Rana temporaria & AY326063 & 2 & Ranidae \\
\hline Scaphiophryne marmorata & AY364345, AY364367 & 1 & Microhylidae \\
\hline Schismaderma carens & AY325997 & 2 & Bufonidae \\
\hline Scinax boulengeri & AY843755 & 3 & Hylinae \\
\hline Stefania schuberti & AY843768 & 3 & Hemiphractinae \\
\hline Trichobatrachus robustus & AY843773 & 3 & Astylosternidae \\
\hline Xenopus laevis & NC 001573 & 4 & Pipidae \\
\hline
\end{tabular}

Total DNA was extracted from liver or toe, following a phenol-chloroform-isoamyl alcohol extraction protocol (Medrano et al. 1990). The fragments of $12 \mathrm{~S}$ and $16 \mathrm{~S}$ mitochondrial genes were obtained by PCR utilizing the primers H1478 (5'-TGACT GCAGA GGGTG ACGGG CGGTG TGT-3') and L1091 (5'-AAAAA GCTTC AAACT GGGAT TAGAT ACCCC ACTAT-3') for 12S (Kocher et al. 1989), and $16 \mathrm{Sbr}-\mathrm{H}$ (5'-CCGGT CTGAA CTCAG ATCAC GT-3') and 16Sar-L (5'-CGCCT GTTTA TCAAA AACAT-3') for 16S (Palumbi et al. 1991). The PCR reaction mixture consisted of $2.5 \mathrm{mM} \mathrm{MgCl}{ }_{2}, 100 \mu \mathrm{M}$ of each dNTP, $0.67 \mu \mathrm{M}$ of each primer, $0.9 \mathrm{U}$ Taq polymerase (Invitrogen) and $1 \mu \mathrm{L}$ total DNA. The thermal profile consisted of a initial step of denaturation at $94^{\circ} \mathrm{C}$ by $1 \mathrm{~min}$, followed by 35 to 38 cycles of $20 \mathrm{~s}$ of denaturation at $94^{\circ} \mathrm{C}, 30$ $\mathrm{s}$ of annealing at $56-61{ }^{\circ} \mathrm{C}$ and $45 \mathrm{~s}$ of extension at $72{ }^{\circ} \mathrm{C}$, finalizing with $10 \mathrm{~min}$ of extension at $72{ }^{\circ} \mathrm{C}$. PCR products were purified using the Qiaquick kit (Qiagen). The fragments of both genes were sequenced in both directions in an
ABI 377 automated sequencer (Applied Biosystems). Sequences of both genes were obtained for one individual of each species, and were edited with the BioEdit program, version 5.0.9 (Hall 1999). The sequences were aligned with ClustalX program (Thompson et al. 1997), using several combinations of multiple alignment parameters to identify the ambiguous alignment regions. We used parameter values between five and 20 for the gap opening parameter and between 0.1 and 2 for the gap extension parameter. Then, the different alignments were compared with other analyses based on models of secondary structure of the mitochondrial rRNAs obtained in anurans (Ruvinsky \& Maxson 1996, Austin et al. 2002) to check the correct identification of homologous variable segments.

Phylogenetic reconstructions were performed using the methods of maximum parsimony (MP), maximum likelihood (ML) and Bayesian inference (BI) with the alignment obtained with intermediate alignment parameters (see Results). A partition 
homogeneity test (the ILD test of Farris et al. 1995) performed with the PAUP* program version 4.0b10 (Swofford 2002) for the alignment without ambiguous alignment regions was utilized to decide whether the two genes could be used in a combined analysis. We performed MP analyses with PAUP* using the matrix containing both genes of the complete alignment and other without ambiguous segments. The heuristic searches were conducted using the tree-bisectionreconnection (TBR) branch-swapping algorithm, treating the gaps as missing data and considering all sites equally weighted. The statistical support was calculated using the nonparametric bootstrap method (Felsenstein 1985) with 1,000 pseudoreplicates. The ML analysis was also performed with PAUP*, incorporing the model of nucleotide evolution obtained in Modeltest version 3.5 (Posada and Crandall 1998) with the Akaike's Information Criterion (AIC). Statistical support was not calculated for this analysis. BI analyses were performed using the MrBayes program version 3.0B 4 (Huelsenbeck \& Ronquist 2001). The program was run for $5,000,000$ generations, sampling every 1,000 from four independent chains. The analysis was repeated two times to determine the convergence in the topologies obtained. The model assumed in these analyses was that estimated with Modeltest. To construct the consensus tree, the first 500 sampled trees were eliminated.

\section{RESULTS}

The lengths of the sequences obtained ranged from 344 to 380 bases for the gene $12 \mathrm{~S}$ and from 523 to 555 bases for $16 \mathrm{~S}$. We chose the alignment obtained with intermediate values of the alignment parameters to make the phylogenetic reconstructions (gap opening parameter: 10; gap extension parameter: 1.0), since this showed a better correspondence with the position and length of the variable regions previously identified in alignments based on models of secondary structure. The length of the complete alignment was 416 nucleotide sites for the $12 \mathrm{~S}$ gene and 556 for the $16 \mathrm{~S}$ gene. This alignment was reduced to 353 and 498 sites, respectively, after deleting ambiguous segments. The partition homogeneity test performed with this last alignment, indicated that it is possible to analyze the two genes simultaneously $(\mathrm{P}=0.07)$. The MP analysis of this reduced data set, based in 479 informative sites, found 26 trees with a length of 4,936 steps and a rescaled consistency index (RCI) of 0.1995 . The analysis with the complete alignment produced similar topologies but the RCI was reduced to 0.0947 . These $26 \mathrm{MP}$ trees showed similar topologies in the case of major clades, and among those trees the differences involved mainly terminal nodes and the relative positions of some clades within Hyloidea. Figure 2 shows one of the 26 trees, indicating the significant (over $50 \%$ ) bootstrap values along the nodes. The ML and BI analyses were performed using the model GTR $+\Gamma+I$ (General Time Reversible with a gamma-shape parameter and proportion of invariant sites). The model parameters were: frequencies $\mathrm{A}=$ $0.3711, \mathrm{C}=0.2240, \mathrm{G}=0.1734, \mathrm{~T}=0.2315$; rates of change $\mathrm{A}-\mathrm{C}=4.1990, \mathrm{~A}-\mathrm{G}=8.6884$, $\mathrm{A}-\mathrm{T}=5.4571, \mathrm{C}-\mathrm{G}=0.3703, \mathrm{C}-\mathrm{T}=29.7523$, $\mathrm{G}-\mathrm{T}=1.0000$; proportion of invariable sites (I) $=0.2886 ;$ and $\alpha=0.5834$. The BI consensus trees were almost identical to the ML tree, therefore we only show the ML phylogram indicating BI values of posterior probability above 0.95 (mean values of both BI analyses) (Fig. 3).

The MP and ML-BI trees showed similar topologies (Fig. 2 and 3), where the following clades can be identified: Neobatrachia, Hyloidea, Ranoidea and Limnodynastidae + Myobatrachidae + Calyptocephalellini (Caudiverbera and Telmatobufo). One difference between the analyses is the relative position of these clades with regard to the species of Heleophrynidae, Nasikabatrachidae and Sooglossidae. The nodes that define the relationships among all of theses clades have low support in all the analyses, a result pointed out by other authors (Biju \& Bossuyt 2003, Darst \& Cannatella 2004). The analyses further differ in the relationships among species of Hyloidea, where most nodes do not have statistical support, a result that is consistent with the analyses of Darst \& Cannatella (2004). Most species of Telmatobiinae are contained in this clade, except Caudiverbera and Telmatobufo. Thus, all the analyses support a polyphyletic definition of the subfamily Telmatobiinae. The species of each genus of 
Telmatobiinae grouped together with high values of statistical support in MP and BI analyses, except for Hylorina, which grouped with Batrachyla. Among Chilean species, the following groups of genera also showed significant support values: Alsodes + Eupsophus, Atelognathus + Batrachyla + Hylorina, and Insuetophrynus + Rhinoderma (in this case with support only from BI analysis). The species of Telmatobius appear as the sister group of ceratophryine species, while Pleurodema groups with other leptodactyline species, although in both cases without significant support values.

\section{DISCUSSION}

The topologies obtained with different methods of phylogenetic reconstruction, show that telmatobiine frogs are a polyphyletic assemblage. More importantly, the relationship of Caudiverbera and Telmatobufo with the Australasian families Myobatrachidae and Limnodynastidae, reveals a high degree of evolutionary divergence among Chilean amphibians. From a systematic point of view, this study confirms the exclusion of Calyptocephalellini from Hyloidea, which was suggested by previous studies where only Caudiverbera was included (San Mauro et al. 2005, Wiens et al. 2005). The closest affinities of faunistic and floristic elements from temperate forests of South America with elements of temperate regions from Australasia indicate an hybrid origin for the South American biota (Crisci et al. 1991, Sanmartín \& Ronquist 2004). This pattern is observed in other taxa from temperate forests from Chile, for instance, among certain species of the genus Nothofagus (Knapp et al. 2005) and the marsupial Dromiciops gliroides (Orden Microbiotheria; Palma \& Spotorno 1999, Cardillo et al. 2004).

The rest of telmatobiine species and Rhinoderma darwinii are comprised of four groups within Hyloidea although the low support values do not permit to clarify the relationships among these taxa and other hyloid families. The clades observed among the genera of telmatobiines in this study (Fig. 2 and 3 ) differ in general with previous hypotheses based on morphological evidence (Fig. 1C, 1D,
$1 \mathrm{E}$ and $1 \mathrm{~F})$. However, it must be noted that some of these groupings have support from other types of evidence and have been observed in other molecular studies. Thus the relationship between Alsodes and Eupsophus is supported by morphological characters which were the basis for considering them a single genus by some authors (Grandison 1961, Cei 1962, Lynch 1971). This clade was also observed by Faivovich et al. (2005) in an analysis that included two species of those genera. Similarly, there is morphological and molecular evidence (lactate dehydrogenase) to sustain a relationship between Batrachyla and Hylorina (Díaz 1981, 1986, Basso 1994). The relationship of Atelognathus with these last two genera is not in agreement with previous morphological studies, but was found by Faivovich et al. (2005) who recovered a clade formed by Atelognathus and Batrachyla species. The relationship of the Andean genus Telmatobius with species of Ceratophryinae observed in this study (although without statistical support) was also observed by Darst \& Cannatella (2004), Faivovich et al. (2005) and Wiens et al. (2005), but only these last two studies show significant support values for this relationship. On the other hand, our analyses show that Rhinoderma and Insuetophrynus are their own closest relatives, two taxa not included simultaneously in previous molecular studies. This is a rather unexpected result due to the accentuated morphological divergence between these species. Of special relevance for the systematics of the Chilean leptodactylids is the position of the leptodactyline Pleurodema. Various authors have emphasized the morphological similarities between the genera Pleurodema and Eupsophus, which would indicate a close relationship between these two taxa (Lynch 1971, Duellman \& Veloso 1977). Our analyses show that Pleurodema is related to other leptodactylines, a result consistent with that of Faivovich et al. (2005). However, in contrast with the results of these authors, this relationship has no statistical support in our analyses. It is important to note that the phylogenetic signal also allowed the observation of divergence events within genera, specifically, the separation of Eupsophus emiliopugini (Formas 1980) and that of Alsodes nodosus (Díaz \& Veloso 1979) from the rest of the species of their respective genera. 

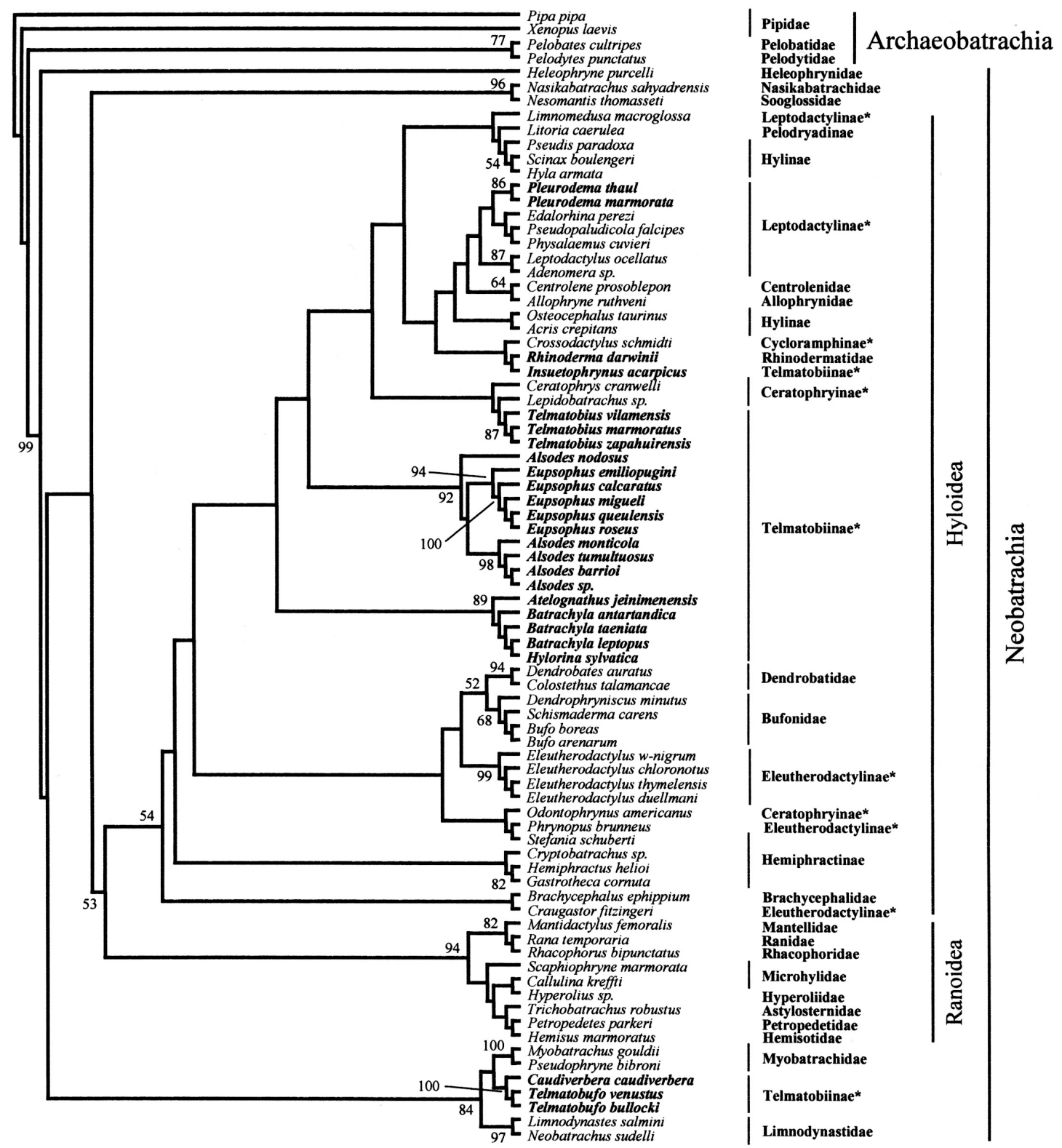

Fig. 2: One of the 26 cladograms obtained by maximum parsimony utilizing 851 nucleotide sites of the $12 \mathrm{~S}$ and $16 \mathrm{~S}$ genes from 80 taxa, considering gaps as missing data. The species used as outgroup belong to the archaeobatrachian families Pipidae, Pelobatidae and Pelodytidae. The assignment of species to families and subfamilies was based on Frost (2004). Numbers above the nodes correspond to bootstrap values from 1000 pseudoreplicates. Only bootstrap values above 50 are shown. Familial or subfamilial assignment (only in the case of Leptodactylidae and Hylidae) for all the species and the main recognized groups in the order Anura are indicated. The taxa for which we obtained sequences in this study are written in bold case, whereas the subfamilies belonging to Leptodactylidae are marked with an asterisk.

Uno de los 26 cladogramas obtenidos por máxima parsimonia utilizando 851 sitios nucleotídicos de los genes $12 \mathrm{~S}$ y $16 \mathrm{~S}$ de 80 taxa, considerando los gaps como datos faltantes. Las especies utilizadas como grupo externo pertenecen a las familias de Archaeobatrachia Pipidae, Pelobatidae and Pelodytidae. La asignación de las especies a familias y subfamilias se basó en Frost (2004). Los números sobre los nodos corresponden a valores de bootstrap de 1000 seudorréplicas. Solo se muestran los valores de bootstrap sobre 50. Se indican la familia o subfamilia (solo en el caso de Leptodactylidae e Hylidae) a que pertenece cada especie y las principales agrupaciones reconocidas en el orden Anura. Los taxa de los cuales se obtuvieron secuencias en este estudio se destacan en negrilla, mientras que las subfamilias pertenecientes a Leptodactylidae se indican con un asterisco. 


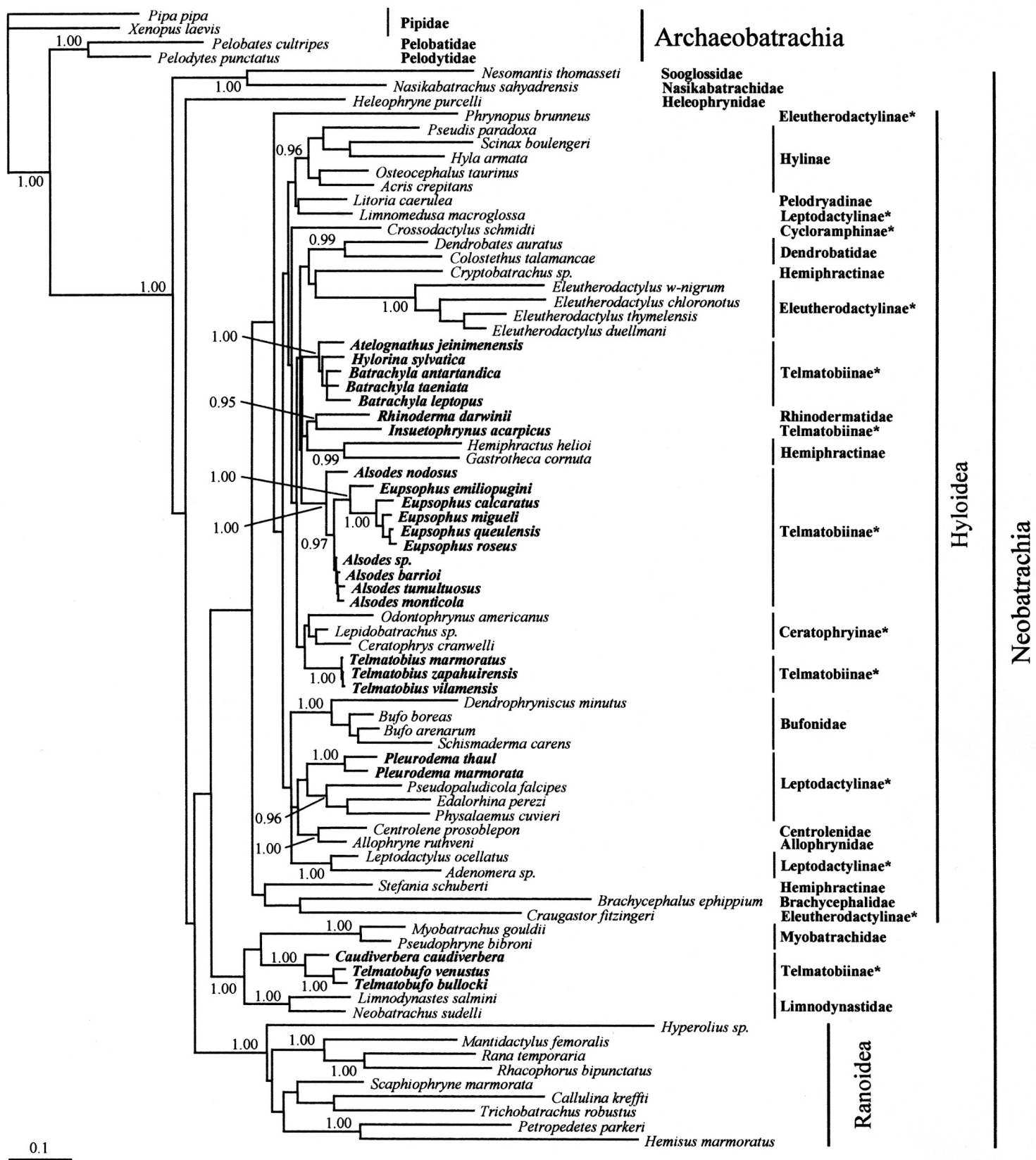

Fig. 3: Maximum likelihood phylogram constructed with 851 nucleotide sites of the $12 \mathrm{~S}$ and $16 \mathrm{~S}$ genes of 80 taxa. The species used as outgroup belong to the archaeobatrachian families Pipidae, Pelobatidae and Pelodytidae. The assignment of species to subfamilies was based on Frost (2004). Numbers above the nodes correspond to posterior probabilities of the Bayesian analysis for a distribution constructed with 4,500 sampled trees. Only posterior probability values above 0.95 are shown. The length of the branches is proportional to the number of inferred nucleotide substitutions. The line on the left inferior corner represents the expected nucleotide substitutions per site according to the maximum likelihood analysis. The nomenclature follows that of Fig. 1.

Filograma de máxima verosimilitud construido con 851 sitios nucleotídicos de los genes $12 \mathrm{~S}$ y $16 \mathrm{~S}$ de 80 taxa. Las especies utilizadas como grupo externo pertenecen a las familias de Archaeobatrachia Pipidae, Pelobatidae and Pelodytidae. La asignación de las especies a familias y subfamilias se basó en Frost (2004). Los números sobre los nodos corresponden a las probabilidades posteriores del análisis bayesiano para una distribución construida con 4.500 árboles muestreados. Solo se muestran los valores de probabilidad posterior sobre 0,95. La longitud de las ramas es proporcional al número de sustituciones nucleotídicas inferidas. La barra del extremo inferior izquierdo representa las sustituciones nucleotídicas esperadas por sitio de acuerdo al análisis de máxima verosimilitud. La nomenclatura es la misma de la Fig. 1. 
It has been postulated that the present distribution of telmatobiine lineages (including Calyptocephalellini) and Rhinodermatidae is the result of physiographic and climatic changes in the late Cenozoic, particularly the elevation of the Andes range and the reduction in the extension of the temperate forests of the southern end of South America (Cei 1962, Vuilleumier 1968, Duellman \& Veloso 1977, Formas 1979). With respect to the origin of these taxa, some authors have proposed that the species which presently inhabit these forests represent relicts of a more specious amphibian fauna which was already diversified in the Cenozoic (Vellard 1957, Cei 1962). An interpretation of this proposal is a unique origin and in situ diversification of these lineages in the southern forests. An alternative hypothesis (Vuilleumier 1968), proposes that the amphibian fauna in the austral forests is composed of four historical elements with different origins, thus the current diversity and high level of endemism observed in this region would be the result of an heterogeneous combination of autochthonous and allochthonous elements. The phylogenetic relationships observed in the present study agree more with this latter scenario than with the hypothesis of a relict fauna raised by Vellard (1957) and Cei (1962), although it is not possible identify the historical elements defined by Vuilleumier (1968) since the relationships of the most temperate forest frogs with other hyloid taxa are not fully resolved.

In summary, our analyses indicate a new panorama for the origin and diversification of the Chilean leptodactylids (Fig. 2 and 3). On one hand, the relationship of Caudiverbera and Telmatobufo with Australasian species and the identification of various clades formed by telmatobiine genera, implies a multiple origin for the amphibians from southern temperate forests. Some of these clades, e.g., Caudiverbera + Telmatobufo or Rhinoderma + Insuetophrynus, might be relicts of lineages more diversified in the past, considering the great morphological divergence between the genera which actually compose them. On the other hand, the relationships observed in this study for telmatobiine frogs invalidate previous taxonomic arrangements proposed in a basis of other kinds of evidence (Table 1). Although it is not possible to propose an alternative taxonomic arrangement for telmatobiinae lineages without resolving the relationships within Hyloidea, our results show a greater than expected taxonomic diversity and evolutionary divergence among Chilean amphibians.

\section{NOTE}

During the revision of the present manuscript, the most comprehensive molecular phylogenetic analysis of living amphibians up to date was published: Frost DR, T Grant, J Faivovich, RH Bain, A Haas, CFB Haddad, RO de Sá, A Channing, M Wilkinson, SC Donnellan, C Raxworthy, JA Campbell, BL Blotto, P Moler, RC Drewes, RA Nussbaum, JD Lynch, DM Green, \& WC Wheeler (2006). The amphibian tree of life. Bulletin of the American Museum of Natural History 297: 1370. The extensive taxa sampling allowed those authors to propose a completely new taxonomic arrangement based on cladistic principles for hyloid frogs. Among these taxonomic changes, three new families were defined that include the genera previously grouped as the subfamily Telmatobiinae (sensu Frost 2004). The genera Caudiverbera and Telmatobufo (along Batrachophrynus) were defined as the family Batrachophrynidae, the sister taxon of the frogs included in the Australo-Papuan families Myobatrachidae and Limnodynastidae. The clade composed by Batrachyla and Atelognathus, along with Telmatobius were arranged with ceratophryine frogs in the family Ceratophryidae, whereas the clade composed by Alsodes, Eupsophus and Hylorina was included in the family Cycloramphidae. Rhinoderma was also incorporated in the family Cycloramphidae, as the sister taxon of Cycloramphus. The genus Insuetophrynus was not included in Frost et al. (2006).

Our analyses agree with some of above mentioned relationships. Specifically, we recovered the clade Caudiverbera + Telmatobufo, a clade that includes Atelognathus, Batrachyla and Hylorina and another composed by Alsodes and Eupsophus, whereas Telmatobius grouped with ceratophryine taxa, although without statistical support. However, our results differ from those of Frost et al. (2006) in the placement of 
Hylorina. Our maximum parsimony and Bayesian inference analyses show high statistical support to place this genus with Atelognathus and Batrachyla. The probable reason for the different placement of Hylorina by Frost et al. (2006) is the low number of nucleotide sites of this taxon used in comparison to the other taxa. The other important difference of our study in comparison with that of Frost et al. (2006) is the relationship of the genus Insuetophrynus, which appears as the closest relative of Rhinoderma.

We are currently working on a new manuscript to explore more fully the relationships of Chilean frogs with a more extensive taxa sampling and data set. This new study will allow us to analyze the causes of such conflicts between our systematic conclusions and those originated by Frost et al. (2006).

\section{ACKNOWLEDGEMENTS}

We acknowledge especially José Núñez for facilitating the samples of IZUA, Fernando Torres and Mauricio Soto for their help in sampling, and Jeanette Vera for her laboratory assistance. Thanks to Gonzalo Collado for his valuable comments on an earlier version of the manuscript. C.C. thanks Leonor Bustamante for her help in translating part of this manuscript. This contribution was partially financed by the Departamento de Postgrado y Postítulo of the Universidad de Chile, Fellowship $\mathrm{N}^{\circ} \mathrm{PG} / 22 /$ 2004 to C.C.

\section{LITERATURE CITED}

AUSTIN JD, SC LOUGHEED, K TANNER, AA CHEK, JP BOGART \& PT BOAG (2002) A molecular perspective on the evolutionary affinities of an enigmatic neotropical frog, Allophryne ruthveni. Zoological Journal of the Linnean Society 134: 335-346.

BÁEZ AM \& ZM DE GASPARINI (1979) The South American herpetofauna: an evaluation of the fossil record. In: Duellman WD (ed) The South American herpetofauna: its origin, evolution and dispersal: 141-156. Museum of Natural History, University of Kansas, Lawrence, Kansas, USA.

BARRIO A \& P RINALDI DE CHIERI (1971) Contribución al esclarecimiento de la posición taxofilética de algunos batracios patagónicos de la familia Leptodactylidae mediante el análisis cariotípico. Physis (Argentina) 81: 673-685.
BASSO NG (1994) Una nueva especie de Batrachyla (Anura: Leptodactylidae: Telmatobiinae) de Argentina. Relaciones filogenéticas interespecíficas. Cuadernos de Herpetología (Argentina) 8: 51-56.

BIJU SD \& F BOSSUYT (2003) New frog family from India reveals an ancient biogeographical link with the Seychelles. Nature 425: 711-714.

CARDILLO M, ORP BININDA-EMONDS, E BOAKES \& A PURVIS (2004) A species-level phylogenetic supertree of marsupials. Journal of Zoology, London 264: 11-31.

CEI JM (1962) Batracios de Chile. Ediciones Universidad de Chile, Santiago, Chile. $128+$ cviii pp.

CEI JM (1970) La posición filética de Telmatobiinae, su discusión reciente y significado crítico de algunos inmunotests. Acta Zoológica Lilloana (Perú) 27: 181-192.

CRAWFORD AJ \& EN SMITH (2005) Cenozoic biogeography and evolution in direct-developing frogs of Central America (Leptodactylidae: Eleutherodactylus) as inferred from a phylogenetic analysis of nuclear and mitochondrial genes. Molecular Phylogenetics and Evolution 35: 536555.

CRISCI JV, MM CIGLIANO, JJ MORRONE \& S ROIGJUNENT (1991) A comparative review of cladistic approaches to historical biogeography of southern South America. Systematic Zoology 42: 152-171.

DARST CR \& DC CANNATELLA (2004) Novel relationships among hyloid frogs inferred from $12 \mathrm{~S}$ and $16 \mathrm{~S}$ mitochondrial DNA sequences. Molecular Phylogenetics and Evolution 31: 462-475.

DÍAZ NF (1981) Aspectos comparativos de lactato deshidrogenasas de cristalinos aplicados a la sistemática de los anfibios chilenos. Medio Ambiente (Chile) 5: 39-44.

DÍAZ NF (1986) Biosistemática de los Leptodactylidae chilenos. Anales del Museo de Historia Natural de Valparaíso (Chile) 17: 65-85

DÍAZ NF (1989) Phenetic and phylogenetic relationships of the Chilean Alsodes and Telmatobius (Amphibian, Leptodactylidae) and proposal of a new genus. Studies on Neotropical Fauna and Environment 24: 25-33.

DÍAZ NF \& A VELOSO (1979) Sistemática y evolución de los anfibios de Chile. Archivos de Biología y Medicina Experimentales (Chile) 12: 59-70.

DÍAZ-PÁEZ H \& JC ORTIZ (2003) Evaluación del estado de conservación de los anfibios chilenos. Revista Chilena de Historia Natural 76: 509-525.

DUELLMAN WE \& L TRUEB (1994) Biology of Amphibians. The John Hopkins University Press, Baltimore, Maryland, USA. 670 pp.

DUELLMAN WE \& A VELOSO (1977) Phylogeny of Pleurodema (Anura: Leptodactylidae): a biogeographic model. Occasional Papers of the Museum of Natural History, University of Kansas 64: 1-46.

FAIVOVICH J, CFB HADDAD, PCA GARCÍA, DR FROST, JA CAMPBELL \& WC WHEELER (2005) Systematic review of the frog family Hylidae, with special reference to Hylinae: phylogenetic analysis and taxonomic revision. Bulletin of the American Museum of Natural History 294: 1-240.

FARRIS JS, M KÄLLERSJÖ, AG KLUGE \& C BULT (1995) Constructing a significance test for incongruence. Systematic Biology 44: 570-572.

FELSENSTEIN J (1985) Confidence limits on phylogenies: an approach using the bootstrap. Evolution 39: 783-791. 
FORD LS \& DC CANNATELLA (1993) The major clades of frogs. Herpetological Monographs 7: 94-117.

FORMAS JR (1979) La Herpetofauna de los bosques temperados de Sudamérica. In: Duellman WD (ed) The South American herpetofauna: its origin, evolution and dispersal: 341-369. Museum of Natural History, University of Kansas, Lawrence, Kansas, USA.

FORMAS JR (1980) The chromosomes of E. calcaratus and the karyological evolution of the genus Eupsophus (Anura: Leptodactylidae) Experientia 36: 1163-1164.

FORMAS JR (1995) Anfibios. In: Simonetti JA, MTK Arroyo, AE Spotorno \& E Lozada (eds) Diversidad biológica de Chile: 314-325. Comisión Nacional de Investigación Científica y Tecnológica, Santiago, Chile.

FORMAS JR \& ND ESPINOZA (1975) Karyological relationships of Telmatobufo (Anura; Leptodactylidae). Herpetologica 31: 429-432.

FROST DR (2004) Amphibian species of the world: an online reference. Version 3.0 (22 August, 2004). Electronic database accessible at http:// research.amnh.org/herpetology/amphibia/ index.html. American Museum of Natural History, New York, USA.

GRANDISON AGC (1961) Chilean species of the genus Eupsophus (Anura, Leptodactylidae). Bulletin of the British Museum (Natural History), Zoology 8: 111-149.

HAAS A (2003) Phylogeny of frogs as inferred from primarily larval characters (Amphibia: Anura). Cladistics 19: 23-89.

HALL TA (1999) BioEdit: a user-friendly biological sequence alignment editor and analysis program for Windows 95/98/NT, Versión 5.0.9, 2001. Nucleic Acids Symposium Series 41: 95-98.

HEYER WR (1975) A preliminary analysis of the intergeneric relationships of the frog family Leptodactylidae. Smithsonian Contributions to Zoology 199: 1-55.

HOEGG S, M VENCES, H BRINKMANN \& A MEYER (2004) Phylogeny and comparative substitution rates of frogs inferred from sequences of three nuclear genes. Molecular Biology and Evolution 21: 1188-1200

HUELSENBECK JP \& F RONQUIST (2001) MrBayes: Bayesian inference of phylogeny. Bioinformatics 17: 754-755.

KNAPP M, K STÖCKLER, D HAVELL, F DELSUC, F SEBASTIANI, \& PJ LOCKHART (2005) Relaxed molecular clock provides evidence for longdistance dispersal of Nothofagus (southern beech). PLoS Biology 3: e14.

KOCHER TD, WK THOMAS, A MEYER, SV EDWARDS, S PÄÄBO, FX VILLABLANCA \& AC WILSON (1989) Dynamics of mitochodrial DNA evolution in animals: amplification and sequencing with conserved primers. Proceedings of the National Academy of Sciences of USA 86: 6196-6200.

LEHR E, G FRITZSCH \& A MÜLLER (2005) Analysis of Andes Frogs (Phrynopus, Leptodactylidae, Anura) phylogeny based on $12 \mathrm{~S}$ and $16 \mathrm{~S}$ mitochondrial rDNA sequences. Zoologica Scripta 34: 593-603.

LYNCH JD (1971) Evolutionary relationships, osteology and zoogeography of leptodactyloid frogs. University of Kansas Publications, Museum of Natural History, Miscellaneous Publication 53: 1238
LYNCH JD (1973) The transition from archaic to advanced frogs. In: Vial JL (ed) Evolutionary biology of the anurans: contemporary research on major problems: 133-182. University of Missouri Press, Columbia, Missouri, USA.

LYNCH JD (1978) A re-assessment of the Telmatobiine leptodactylid frogs of Patagonia. Occasional Papers of the Museum of Natural History, University of Kansas 72: 1-57.

MEDRANO JF, E AASEN \& SHARROW (1990) DNA extraction from nucleated red blood cells. Biotechniques 8: 43.

MERIGGIO V, A VELOSO, S YOUNG \& H NÚÑEZ (2004) Atelognathus jeinimenensis n. sp. de Leptodactylidae para el sur de Chile. Boletín del Museo Nacional de Historia Natural (Chile) 53: 99123.

PALMA RE \& AE SPOTORNO (1999) Molecular systematics of marsupials based on the rRNA $12 \mathrm{~S}$ mitochondrial gene: the phylogeny of Didelphimorphia and of the living fossil microbiotheriid Dromiciops gliroides Thomas Molecular Phylogenetics and Evolution 13: 525535.

PALUMBI SR, A MARTIN, S ROMANO, WO MCMILLAN, L STICE \& G GRABOWSKI (1991) The simple fool's guide to PCR, Version 2.0 Privately published document compiled by Palumbi S. Special Publication of Department of Zoology, University of Hawaii, Honolulu, USA. 44 pp.

POSADA D \& KA CRANDALL (1998) Modeltest: testing the model of DNA substitution. Bioinformatics 14 817-818.

REIG OA (1960) Las relaciones genéricas del anuro chileno Calyptocephalella gayi (Dum. \& Bibr.). Actas y Trabajos del Primer Congreso Latinoamericano de Zoología (La Plata, 1959) 4: 113-131.

ROE BA, D-P MA, RK WILSON \& F-H WONG (1985) The complete nucleotide sequence of the Xenopus laevis mitochondrial genome. Journal of Biological Chemistry 260: 9759-9774.

ROELANTS K \& F BOSSUYT (2005) Archaeobatrachian paraphyly and pangaean diversification of crowngroup frogs. Systematic Biology 54: 111-126.

RUVINSKY I \& L MAXSON (1996) Phylogenetic relationships among bufonoids frogs (Anura: Neobatrachia) inferred from mitochondrial DNA sequences. Molecular Phylogenetics and Evolution 5: $533-547$.

SAN MAURO D, M VENCES, M ALCOBENDAS, R ZARDOYA \& A MEYER (2005) Initial diversification of living amphibians predated the breakup of Pangaea. American Naturalist 165: 590599.

SANMARTÍN I \& F RONQUIST (2004) Southern Hemisphere biogeography inferred by event-based models: plant versus animal patterns. Systematic Biology 53: 216-243.

SAVAGE JM (1973) The geographic distribution of frogs: patterns and predictions. In: Vial JL (ed) Evolutionary biology of the anurans: contemporary research on major problems: 351-445. University of Missouri Press, Columbia, Missouri, USA.

SCHAEFFER B (1949) Anurans from the early Tertiary of Patagonia. Bulletin of the American Museum of Natural History 93: 47-68.

SWOFFORD DL (2002) PAUP*. Phylogenetic Analysis Using Parsimony (*and Other Methods). Version 4. Sinauer Associates, Sunderland, Massachusetts. 
THOMPSON JD, TJ GIBSON, F PLEWNIAK, F JEANMOUGIN \& DG HIGGINS (1997) The ClustalX windows interface: flexible strategies for multiple sequence alignment aided by quality analysis tools. Nucleic Acids Research 25: 48764882.

VELLARD J (1957) Répartition des batracien dans les Andes au sud de l'Equateur. Travaux Institut Français d'Études Andines (Perú) 5: 141-161.

VELOSO A, JL CELIS-DIEZ, PC GUERRERO, M MÉNDEZ, P ITURRA \& JA SIMONETTI (2005) Description of a new Eupsophus species (Amphibia, Leptodactylidae) from the remnants of Maulino forest, central Chile. Herpetological Journal 15: 159-165.

VELOSO A \& J NAVARRO (1988) Lista sistemática y distribución geográfica de anfibios y reptiles de Chile. Bollettino del Museo Regionale di Scienze Naturali, Torino (Italy) 6: 481-539.

Associate Editor: Elie Poulin

Received September 21, 2005; accepted July 12, 2006
VENCES M, J KOSUCH, S LÖTTERS, A WIDMER, K JUNGFER, J KÖHLER \& M VEITH (2000) Phylogeny and classification of poison frogs (Amphibia: Dendrobatidae), based on mitochondrial $16 \mathrm{~S}$ and $12 \mathrm{~S}$ ribosomal RNA gene sequences. Molecular Phylogenetics and Evolution 15: 34-40.

VENCES M, J KOSUCH, R BOISTEL, CFB HADDAD, E LA MARCA, S LÖTTERS \& M VEITH (2003) Convergent evolution of aposematic coloration in Neotropical poison frogs: a molecular phylogenetic perspective. Organisms Diversity and Evolution 3: 215-226.

VUILLEUMIER F (1968) Origin of frogs of Patagonian forests. Nature 219: 87-89.

WIENS JJ, JW FETZNER, CL PARKINSON \& TW REEDER (2005) Hylid frog phylogeny and sampling strategies for speciose clades. Systematic Biology 54: 719-748. 